\title{
Association of homelessness with COVID-19 positivity among individuals visiting a testing center
}

\author{
Tara Kiran 1, 2, 3, 4 MD, MSc tara.kiran@utoronto.ca
}

Amy Craig-Neil ${ }^{1}$ MSc amy.craig-neil@unityhealth.to

Paul Das ${ }^{2,3}$ MD, MSc Paul.Das@unityhealth.to

Joel Lockwood 5,6 MD Joel.lockwood@unityhealth.to

Ri Wang ${ }^{1}$ MMath ri.wang@unityhealth.to

Nikki Nathanielsz' BSc nikki.nathanielsz@mail.utoronto.ca

Esther Rosenthal $^{2,3}$ MD esther.rosenthal@unityhealth.to

Stephen W. Hwang ${ }^{1,8}$ MD, MPH stephen.hwang@unityhealth.to

${ }^{1}$ MAP Centre for Urban Health Solutions, St. Michael's Hospital, University of Toronto, Toronto, Ontario

${ }^{2}$ Department of Family and Community Medicine, St. Michael's Hospital, University of Toronto, Toronto, Ontario

${ }^{3}$ Department of Family and Community Medicine, Faculty of Medicine, University of Toronto, Toronto, Ontario

${ }^{4}$ Institute of Health Policy, Management and Evaluation, University of Toronto, Toronto,

Ontario

${ }^{5}$ Division of Emergency Medicine, Faculty of Medicine, University of Toronto, Toronto, Ontario

${ }^{6}$ Department of Emergency Medicine, St. Michael's Hospital, University of Toronto, Toronto, Ontario

${ }^{7}$ MD program, Faculty of Medicine, University of Toronto, Toronto, Ontario

${ }^{8}$ Division of General Internal Medicine, Department of Medicine, University of Toronto, Toronto, Canada 


\section{Send correspondence to:}

Dr. Tara Kiran, Health Centre at 80 Bond, 80 Bond Street, Toronto, Ontario, Canada M5B 1X1;

tara.kiran@utoronto.ca; phone (416) 864-3011; fax (416) 864-3099

Word count: 664

Number of Tables: 2

\section{Funding statement}

This study was supported by a grant from the St. Michael's Hospital Foundation. The study sponsor had no role in study design, data collection, analysis, interpretation of data, manuscript preparation or the decision to submit for publication.

Dr. Kiran is the Fidani Chair in Improvement and Innovation at the University of Toronto. She is supported as a Clinician Scientist by the Department of Family and Community Medicine at the University of Toronto and at St. Michael's Hospital. She is also supported by the Canadian Institutes of Health Research and Health Quality Ontario as an Embedded Clinician

Researcher.

\section{Conflicts of interest}

The authors declare no conflicts of interest.

\section{Acknowledgements}

We are grateful to Linh Luong and Tadios Tibebu who spent many hours extracting data from paper charts. We thank the many individuals involved in supporting the mobile outreach testing, particularly Dana Whitham, Nicole Gichuru, Chantel Marshall and Linda Jackson, whose leadership and guidance made the outreach possible. We would like to especially acknowledge the daily hard work by staff at the COVID-19 Assessment Centre at St. Michael's Hospital, Sherbourne Health, and the shelter sites. 
medRxiv preprint doi: https://doi.org/10.1101/2021.01.04.20248661; this version posted January 12, 2021. The copyright holder for this preprint (which was not certified by peer review) is the author/funder, who has granted medRxiv a license to display the preprint in perpetuity. It is made available under a CC-BY-NC-ND 4.0 International license .

\section{Introduction}

People experiencing homelessness are at higher risk of acquiring SARS CoV-2 as lack of safe housing makes it difficult to practice physical distancing, hand hygiene, and other preventive measures. ${ }^{1}$ People experiencing homelessness also have higher rates of chronic conditions, making them more vulnerable to COVID-19 complications. ${ }^{2}$ Early in the pandemic, some regions began conducting mobile outreach testing in shelters and detected high rates of infection among asymptomatic residents, especially when there was a known positive case in the shelter. ${ }^{3,4}$ However, it is unclear how often people experiencing homelessness are visiting testing centres and how their test positivity rate differs from that of others visiting the same centre.

The St. Michael's Hospital COVID-19 Assessment Centre (CAC) was one of 116 testing centres opened in Ontario, Canada, shortly after the pandemic began. It is located in Toronto's urban core where a large proportion of the city's homeless population resides. This study examines the association between homelessness and test positivity among people seen at the assessment center.

\section{Methods}

We conducted a retrospective chart audit of all patients tested for COVID-19 at the St. Michael's Hospital CAC from its opening on March 16, 2020 until April 30, 2020. Testing was free for all individuals. Testing criteria changed according to provincial government direction ${ }^{5}$ and was largely limited to symptomatic people who were at high-risk of acquiring COVID-19 due to vulnerable residence, occupation, or high-risk exposure. Vulnerable residence included those unhoused or in homeless shelters. In mid-April, asymptomatic individuals began being tested in specific circumstances (e.g. local outbreak, clinical exposure). We did not include results from the CAC's outreach testing done at shelters.

Data were collected on a standardized form by registered nurses, nurse practitioners or physicians. We classified people as homeless based on data from the chart and the hospital registration address field. We used a Chi-squared test or Mann-Whitney test to compare demographics, medical co-morbidities, symptoms, and test positivity between people who did and did not experience homelessness. We performed a logistic regression analysis to estimate the odds of testing positive for COVID-19 for people who were and were not homeless after adjustment for age, sex, and medical co-morbidity.

\section{Results}

Between March and April 2020, 214 (10.4\%) of 2050 unique individuals who were tested at the St. Michael's Hospital CAC were homeless. People experiencing homelessness were more likely to be male $(75.7 \%$ vs $37.0 \%, p<0.001)$ and less likely to have a health insurance card $(71.5 \%$ vs. $97.6 \%, p<0.001$ ) (Table 1). There was no statistical difference in mean age, but the age distribution was different $(p<0.001)$ with fewer people experiencing homelessness between age 25 to 49. There were no statistical differences in reported symptoms but people experiencing homelessness were more likely to have at least one medical co-morbidity $(70.3 \%$ vs. $53.4 \%$, 
medRxiv preprint doi: https://doi.org/10.1101/2021.01.04.20248661; this version posted January 12, 2021. The copyright holder for this preprint (which was not certified by peer review) is the author/funder, who has granted medRxiv a license to display the preprint in perpetuity.

It is made available under a CC-BY-NC-ND 4.0 International license .

$\mathrm{p}<0.001)$ and abnormal vital sign $(38.1 \%$ v. $26.0 \%, p<0.01)$ compared to those not experiencing homelessness.

People experiencing homelessness were more likely to test positive for COVID-19 compared to those not experiencing homelessness $(15.4 \%$ vs. $6.7 \%, p<0.001)$. People experiencing homelessness had higher odds for testing positive even after adjustment for age, sex, and the presence of any medical co-morbidity (OR 2.41, 95\% Cl 1.51 to 3.76, $\mathrm{p}<0.001$ ) (Table 2).

\section{Discussion}

In this study of individuals visiting a COVID-19 testing centre early in the pandemic, people experiencing homelessness had more than twice the odds of testing positive than those not experiencing homelessness. The higher positivity was present even when accounting for differences in age, sex, and medical co-morbidity. A limitation of this study is that it reflects testing at a single centre early in the pandemic when testing was largely limited to those living or working in high-risk settings. The City of Toronto has since moved more than 3500 individuals experiencing homelessness into spaces that allow for physical distancing. ${ }^{6}$ Research is needed to understand whether these efforts have lowered the rates of COVID-19 infection among people who are unhoused. Our results confirm that people experiencing homelessness are at high-risk of COVID-19 and that targeted efforts are needed to reduce transmission rates.

\section{References}

1. Perri M, Dosani N, Hwang SW. Covid-19 and people experiencing homelessness: Challenges and mitigation strategies. CMAJ. 2020;192(26):E716-E719.

2. Fazel S, Geddes JR, Kushel M. The health of homeless people in high-income countries: Descriptive epidemiology, health consequences, and clinical and policy recommendations. The Lancet. 2014;384(9953):1529-1540.

3. Baggett TP, Keyes $\mathrm{H}$, Sporn N, Gaeta JM. Prevalence of sars-cov-2 infection in residents of a large homeless shelter in boston. Jama. 2020;323(21):2191-2192.

4. Mosites E, Parker EM, Clarke KE, et al. Assessment of sars-cov-2 infection prevalence in homeless shelters-four us cities, march 27-april 15, 2020. Morbidity and Mortality Weekly Report. 2020;69(17):521.

5. Ministry of Health and Long-Term Care. Covid-19 guidance for the health sector. http://www.health.gov.on.ca/en/pro/programs/publichealth/coronavirus/2019 guidan ce.aspx\#health. Accessed December 1, 2020.

6. City of toronto covid-19 response for people experiencing homelessness. Aug 7, 2020; https://www.toronto.ca/news/city-of-toronto-covid-19-response-for-peopleexperiencing-homelessness/. Accessed Sep 14, 2020. 
medRxiv preprint doi: https://doi.org/10.1101/2021.01.04.20248661; this version posted January 12, 2021. The copyright holder for this preprint (which was not certified by peer review) is the author/funder, who has granted medRxiv a license to display the preprint in perpetuity. It is made available under a CC-BY-NC-ND 4.0 International license .

Table 1. Comparison of demographic characteristics, symptoms, medical co-morbidity, and vital signs between people who did and did not experience homelessness

\begin{tabular}{|c|c|c|c|c|}
\hline & $\begin{array}{l}\text { Homeless } \\
(n=214)\end{array}$ & $\begin{array}{l}\text { Not homeless } \\
(n=1836)\end{array}$ & $\begin{array}{l}\text { All } \\
(n=2050)\end{array}$ & P-value \\
\hline Age, Median (IQR) & $40.3(31.0-55.5)$ & $41.7(32.1-54.0)$ & $41.5(32.1-54.1)$ & 0.64 \\
\hline $\begin{array}{l}\text { Age category } \\
\begin{array}{l}0-15 \\
16-24 \\
25-49 \\
50-64 \\
65+\end{array}\end{array}$ & $\begin{array}{l}4(1.9 \%) \\
23(10.8 \%) \\
111(51.9 \%) \\
58(27.1 \%) \\
18(8.4 \%)\end{array}$ & $\begin{array}{l}14(0.8 \%) \\
90(4.9 \%) \\
1130(61.6 \%) \\
497(27.1 \%) \\
105(5.7 \%)\end{array}$ & $\begin{array}{l}18(0.9 \%) \\
113(5.5 \%) \\
1241(60.5 \%) \\
555(27.1 \%) \\
123(6.0 \%)\end{array}$ & $<0.001$ \\
\hline $\begin{array}{l}\text { Sex } \\
\text { Female } \\
\text { Male } \\
\end{array}$ & $\begin{array}{l}52(24.3 \%) \\
162(75.7 \%)\end{array}$ & $\begin{array}{l}1155(63.0 \%) \\
678(37.0 \%)\end{array}$ & $\begin{array}{l}1207 \text { (59.0\%) } \\
840(41.0 \%)\end{array}$ & $<0.001$ \\
\hline OHIP available & $153(71.5 \%)$ & $1792(97.6 \%)$ & 1945 (94.9\%) & $<0.001$ \\
\hline $\begin{array}{l}\text { Symptoms } \\
\text { Any symptoms } \\
\text { No symptoms } \\
\text { Cough } \\
\text { Fever } \\
\text { Shortness of Breath } \\
\text { Other }\end{array}$ & $\begin{array}{l}172(83.1 \%) \\
35(16.9 \%) \\
100(48.3 \%) \\
27(13.0 \%) \\
25(12.1 \%) \\
91(44.0 \%)\end{array}$ & $\begin{array}{l}1563(85.8 \%) \\
258(14.2 \%) \\
892(49.0 \%) \\
193(10.5 \%) \\
229(12.6 \%) \\
827(45.4 \%) \\
\end{array}$ & $\begin{array}{l}1735(85.6 \%) \\
293(14.5 \%) \\
992(48.9 \%) \\
220(10.8 \%) \\
254(12.5 \%) \\
918(45.3 \%)\end{array}$ & $\begin{array}{l}0.34 \\
0.85 \\
0.26 \\
1.00 \\
1.00\end{array}$ \\
\hline $\begin{array}{l}\text { Medical co-morbidity } \\
\text { Any co-morbidity } \\
\text { No co-morbidity } \\
\text { Chronic lung disease } \\
\text { Diabetes } \\
\text { Heart disease or stroke } \\
\text { Immunosuppressed } \\
\text { Smoker } \\
\text { Other }\end{array}$ & $\begin{array}{l}135(70.3 \%) \\
57(29.7 \%) \\
25(13.0 \%) \\
14(7.3 \%) \\
14(7.3 \%) \\
9(4.7 \%) \\
85(44.3 \%) \\
66(34.4 \%)\end{array}$ & $\begin{array}{l}911(53.4 \%) \\
796(46.6 \%) \\
179(10.5 \%) \\
133(7.8 \%) \\
83(4.9 \%) \\
61(3.6 \%) \\
190(11.1 \%) \\
485(28.4 \%)\end{array}$ & $\begin{array}{l}1046(55.1 \%) \\
853(44.9 \%) \\
204(10.7 \%) \\
147(7.7 \%) \\
97(5.1 \%) \\
70(3.7 \%) \\
275(14.5 \%) \\
551(29.0 \%)\end{array}$ & $\begin{array}{l}<0.001 \\
0.85 \\
0.24 \\
0.76 \\
1.00 \\
<0.001 \\
0.39\end{array}$ \\
\hline Any abnormal vital sign* & $48(38.1 \%)$ & $288(26.0 \%)$ & $336(27.2 \%)$ & $<0.01$ \\
\hline
\end{tabular}

*Abnormal vital sign defined as heart rate $>110$, oxygen saturation $<92 \%$, and/or respiratory rate $>24$ 
medRxiv preprint doi: https://doi.org/10.1101/2021.01.04.20248661; this version posted January 12, 2021. The copyright holder for this preprint (which was not certified by peer review) is the author/funder, who has granted medRxiv a license to display the preprint in perpetuity. It is made available under a CC-BY-NC-ND 4.0 International license.

Table 2. Odds of individuals experiencing homelessness testing positive for COVID-19 compared to individuals not experiencing homelessness after adjustment for age, sex, and any medical comorbidity

\begin{tabular}{|l|l|l|l|l|l|}
\hline Description & Covariate & OR & P-value & Lower 95\% & Upper 95\% \\
\hline Homelessness & $\begin{array}{l}\text { Homeless vs. Not } \\
\text { homeless }\end{array}$ & 2.41 & $<0.001$ & 1.51 & 3.76 \\
\hline Age & $\begin{array}{l}\text { Per increase of } 1 \\
\text { year }\end{array}$ & 1.00 & 0.73 & 0.99 & 1.01 \\
\hline Sex & Male vs. Female & 1.12 & 0.52 & 0.78 & 1.60 \\
\hline $\begin{array}{l}\text { Any medical } \\
\text { co-morbidity }\end{array}$ & $\begin{array}{l}\text { Any co-morbidities } \\
\text { vs. No co-morbidities }\end{array}$ & 0.99 & 0.97 & 0.69 & 1.43 \\
\hline
\end{tabular}

